\title{
The Influence of Economic Value Added and Return on Assets on Created Shareholders Value: A Comparative Study in Jordanian Public Industrial Firms
}

\author{
Sliman S. Alsoboa ${ }^{1}$ \\ ${ }^{1}$ College of Business Administration and Economics, Al-Hussein Bin Talal University, Ma'an, Jordan \\ Correspondence: Sliman Alsoboa, College of Business Administration and Economics, Al-Hussein Bin Talal \\ University, Ma’an, Jordan. E-mail: sliman_alsoboa@yahoo.com
}

Received: January 19, 2017

Accepted: February 14, 2017

Online Published: March 10, 2017

doi:10.5539/ijef.v9n4p63

URL: https://doi.org/10.5539/ijef.v9n4p63

\begin{abstract}
This study has two main objectives. The first one is to address the relationship between Economic Value Added (EVA) and Created Shareholders Value (CSV) in Jordanian public industrial firms (JPIF), comparing to the Return on Assets (ROA) over the period 2011-2015. The second objective is to address the possible superiority of EVA to ROA by explaining the changes in CSV for JPIF. In this study, CSV is measured using two models; Fernandez model and market value added model. Multiple and simple regressions were used in the study. These analyses have shown, generally, that the superiority of EVA in predicting and evaluating the CSV could be put into a conclusive and positive light compared to ROA. However, the results suggested that one financial measure cannot be enough to measure neither CSV nor firms' performance. Therefore, this study highly recommends that JPIF use a combination of different measure in assessing and evaluating their value and performance, especially modern indicators.
\end{abstract}

Keywords: economic value added, return on assets, created shareholders value, market value added, Fernandez model, Jordan

\section{Introduction}

In recent years, the main objectives of corporations have shifted to the creation of value and achieving satisfactory returns via increasing profitability and shareholders' wealth. Consequently, all the available resources are to be exploited and managed wisely to enhance these objectives. Among other stakeholders, the creation of value to shareholders is an important key to success in a developed business environment. In general, it is accepted that the value is created when the firm generates or sustains returns that are more than its cost of capital. There are hence many indicators that can be used to measure CSV including EVA.

However, the measurement and evaluation of value and the performance of firms have become very important concerns. Investors usually make their investment decision based on the best choice of alternatives, which depend primarily on the size and timeliness of the expected cash flows generated from the firm's operations. Therefore, in order to create value for shareholders, management is required to maximise shareholder returns (Rappaport, 1986; Monks \& Minow, 2011; Jensen, 2002; Smith, 2003).

From this perspective, Fernandez (2001) has introduced a measure for CSV (hereafter CSV-F).He believes that the firm will achieve CSV when the required return to equity exceeds the cost of equity. Three important indicators constitute the structure of the Fernandez Model; which are equity market value, shareholder return and the cost of equity. MVA is another well-known measure of shareholder value introduced by Stewart (1991).According to this indicator, the focus in increasing shareholders' wealth is placed upon maximising the market capitalisation in comparison with the capital invested.

From another perspective, for a long time the use of traditional accounting data for the purpose of measuring and evaluating value and performance of firms has been criticised because its preparation is based on generally accepted accounting principles (GAAP), or based on International Accounting Standards (IASs).These principles and standards permit the estimation of many figures, in addition to the diversity of applications; however, this leads to the accounting of distorted data. In this regard, as a financial measure, EVA plays a vital role in allowing adjustments to accounting data to reflect the true economic status of the firm. Furthermore, EVA has become a 
popular tool by which the firm can maximise the shareholder value.

As a measure of performance, EVA comes closer than any other tool to representing the true economic profit of an enterprise. It is directly linked to the creation of shareholders' wealth over time (Stern et al., 1995). Shil (2009) defines EVA as a value-based performance measure that gives importance to value creation by company management on behalf of the owners. Bahadur and Deb (2013) refer to how "EVA attempts to understand whether a business creates sufficient surplus to cover the cost of its capital or to fulfill the shareholders' expectation into value creation" (p. 233).

This study intends to provide empirical evidence on the influence of EVA on CSV in the JPIF, comparing it to ROA as a proxy of traditional performance measures. Two models, CSV-F and MVA, have been utilised to measure CSV in JPIF over the period of 2011-2015. Therefore, this study has two main objectives. The first one is to address the relationship between EVA and CSV in JPIF listed on ASE compared to ROA over the period of 2011-2015. The second objective is to address the possible superiority of EVA to ROA for explaining the changes of CSV for JPIF for the years 2012-2015.

This study has suggested that one financial measure cannot be enough to measure both Created Shareholders Value and firms' performance. Therefore, JPIF can use a combination of measures to assess and evaluate CSV and financial performance. Generally, the superiority of EVA in predicting and evaluating the CSV could be put into a conclusive and positive light compared to ROA. However, a few studies have been conducted in Jordan to assess the relationships between traditional and modern financial measures relating to CSV. Therefore, this study may be the first to address these relationships in Jordan, especially in industrial firms.

The paper will proceed as follows. The second section reviews the related literature. The third section presents a brief theoretical framework of the main topics and the development of our hypotheses. The fourth section describes the methodology of the study, including the measurement of variables. The fifth section supplies the empirical results. The sixth section summarises the conclusions, while the seventh section outlines the limitations.

\section{Literature Review}

Many studies address the relationships between different measures of wealth creation and different performance measures. This section will summarise the most important related literature. For instance, Sirbu (2012) notes that "EVA promises an effective way to manage shareholder value. It aligns management's objectives with those of the shareholders, improves accountability and enables better performance analysis" (p. 305).

Hence, many studies have addressed the relationship between CSV and EVA. Nuroush et al. (2004), as cited in Abdoli et al. (2012) indicate that "EVA is a better index for predicting the created shareholders value and represents the management's capability in increasing the company's value (shareholders' wealth)" (p. 876). A study conducted by Panigrahi et al. (2014) reveals that "there is a positive and significant relationship between EVA and shareholder's wealth maximization"(p. 280). Bao and Bao (1999) have revealed that the "EVA is positively and significantly correlated with the firm value" (p. 161). Meanwhile, Abdoli et al. (2012) also point out that EVA has a significant relationship with shareholders' created wealth. On the other hand, it is important to mention that EVA itself has classified as a measure of CSV (see, for example, Sakthivel, 2011; Suresh \& Sengottaiyan, 2015; Kaur \& Narang, 2008). However, the present study has to deal with EVA as a performance measure.

However, this study addresses two measures of CSV; namely, CSV-F and MVA. In terms of measuring CSV via the Fernandez model, we noted a shortage of research in the field. However, Fernandez (2001) has concluded that EVA does not measure wealth creation properly, whereas Fernandez and Reinoso (2003) have found a weak correlation between EVA and created shareholder value. In another study done by ElMir and Seboui (2006), a non-significant relationship was found between EVA and CSV-F. A similar result was found by Nekounam et al. (2013) when they refer to the lack of a relationship between EVA and CSV-F. From the other perspective, a positive correlation was found between the difference of these two variables (i.e. CSV-EVA) when they controlled by governance mechanisms and earnings management (ElMir \& Seboui, 2006). Other studies have found different results; for instance, Imanzadeh (2014) has found a direct link between EVA and CSV-F.

Unlike CSV-F, a lot of studies have assessed the association between MVA and EVA. From a theoretical view of point, the literature has referred to a direct association between EVA and MVA (e.g. DeWet, 2005; Brigham \& Ehrhardt, 2014; Aloy \& Alfred, 2014). Furthermore, prior studies have found a statistically significant relationship between EVA and MVA (Stern, Shiely, \& Ross, 2001; Pinto \& Santos, 2011; Sharma \& Kumar, 2012; Pourali \& Roze, 2013). Furthermore, Banerjee (2000, p. 23) emphasises that "MVA can be well predicted by estimated 
future EVA streams".

On the other hand, the relationships between EVA, accounting performance measures and CSV were addressed in many comparative studies. Mixed results were found in this regard. Some of prior studies have concluded that EVA has a stronger correlation with MVA compared to accounting measures(e.g., Grant, 1996; Uyemura et al., 1996; Paula \& Elena, 2009; Sichigea \& Vasilescu, 2015). In this context, Nakhaei and Hamid (2013) also indicate that "there is meaningful correlation between EVA, and ROE with MVA, but there is not meaningful association between ROA and MVA" (p. 2). Yaghoob and Akkaf (2007) also recognize that there are meaningful relationships between EVA, residual income, return on sales and return on investment with MVA.

Meanwhile, Ghanbari and More (2007) have found "strong evidence that EVA is greater to the traditional performance appraising, and it is the best internal evolution of firm success in adding value to shareholders' investments" (p. 7). Madhavi and Prasad (2015) have also affirmed that, "EVA is a better predictor of market value of the firms as compared to EPS and is successful in indicating stronger relationship and relevance to capital markets than other traditional measures" (p. 49). Finally, Roze et al. (2013) have examined the relationship between moderated EVA, as well as some accounting and financial criteria such as ROS, EPS, ROA and ROE, with MVA as an external indicator of value-creation. They have indicated that all the study variables are in a direct linear and significant relationship with MVA.

However, the literature also contains reverse findings. For instance, Bhasin and Shaikh (2013, p. 107; Bhasin, 2013, p. 185) indicate that, "there is no strong evidence to support Stern Stewart's claim that EVA is superior to the traditional performance measures in its association with MVA". In turn, Aloy and Alfred (2014) have found no association between EVA and MVA. They also reveal that EVA has no profound impact on MVA. DeWet (2005) concluded that EVA doesn't has a strongest relation with MVA compared to operating cash flow, return on assets, earning per share and dividends per share.

In addition, Ramana (2005) suggests that EVA does not outperform common accounting criteria, such as NOPAT and EBIT. Furthermore, the result of the study conducted by Kim (2006) does not "support the hypothesis that EVA is superior to traditional accounting measures in association with equity market value" (p. 34). He also points out that NOPAT and FCF are more highly correlated with market value rather than EVA. Thus, accounting measures, such as NOPAT, are also found superior to EVA in its association with firm values (Biddle et al., 1997; Clinton \& Chen, 1998).

\section{Theoretical Framework}

\subsection{Created Shareholder Value}

The creation or destruction of value to the capital employed is recognised as one of the most important aspects in the evaluation of the performance of an enterprise (Hall, 1998, p. 149). In the theoretical foundations of a firm's management, there are two approaches that can be followed by the managers to creating value: the shareholder value approach and the stakeholders' value approach. The shareholder value approach refers to a "Management philosophy that regards maximization of shareholders' equity as its highest objective. It attempts to increase this value by following policies that (1) enhance the firm's earnings, (2) increase the market value of its shares, and (3) increase the amount or frequency of the dividend paid" (Business Dictionary, 2016). Alfred Appaport (1986) (as cited in Bierman Jr., 1990) stated that, "The shareholder value approach estimates the economic value of an investment by discounting forecasted cash flows by the cost of capital. These cash flows, in turn, serve as the foundation for shareholder returns from dividends and share-price appreciation" (p. 144). According to Smith (2003)," in the shareholder theory, the primary duty of management is to maximize shareholder returns" (p. 85). In this context, Jensen (2002) recognises that, "value maximization states that managers should make all decisions so as to increase the total long-run market value of the firm" (p. 236). Here, total value is the sum of the values of all financial claims on the firm, including equity, debt, preferred stock and warrants.

Sundaram and Inkpen (2004) give five parts to their argument for why shareholder value maximisation should be the preferred corporate goal. These parts include "the goal of maximizing shareholder value is pro-stakeholder, maximizing shareholder value creates the appropriate incentives for managers to assume entrepreneurial risks, having more than one objective function will make governing difficult, if not impossible, it is easier to make shareholders out of stakeholders than vice versa, and finally, in the event of a breach of contract or trust, stakeholders, compared with shareholders, have protection through contracts and the legal system" (p. 353).

The literature on the measurement of shareholder value has addressed many of measures including EVA, Adjusted EVA, FCF, total business returns, shareholder value analysis, economic profit, cash flow return on investment, market-adjusted total share return, ratio of market value to the book value of shares, shareholders' 
annual returns and shareholders' abnormal returns (CIMA, 2004; Erasmus \& Scheepers, 2008; Maham et al., 2008; Maimako \& Oladele, 2010; Saha, 2015; Farahani et al., 2016). However, the focus of this study is on the CSV in JPIF listed in the Amman exchange stock (ASE) over the period 2011-2015. Two measures of CSV have been addressed in this study, discussed below.

\subsubsection{Fernandez Model}

This measure of Created Shareholders Value was developed by Pablo Fernandez in 2001. In his study, "Shareholder Value Creators and Shareholder Value Destroyers in USA: Year 2000", Fernandez (2001) has defined and quantified CSV for 274 American companies for the years 1998, 1999, 2000, as well as for1993-2000. According to Fernandez and Reinoso (2002), "A company creates value for the shareholder when the shareholder return exceeds the cost of equity (the required return to equity). In other words, a company creates value in one year when it outperforms expectations" (p. 4). However, the technical procedures for computation of this measure will be discussed later in the section on the measurement of variables.

\subsubsection{Market Value Added}

Stewart (1991) introduced MVA as measure of shareholder value. Since then, MVA is frequently referred to as a proxy or measure of CSV (e.g. Kramer \& Peters, 2001, p. 42; DeWet, 2005; Paula \& Elena, 2009, p. 53; Aloy \& Alfred, 2014, p. 127; Madhavi \& Prasad, 2015, p. 49; Nakhaei, 2016, p. 434; Pandya, 2016, p. 40). In addition, MVA has been classified as "an external performance measure, which is considered to be the best index of creation shareholder value" (Nakhaei, 2016, p. 436). For instance, Kramer and Peters (2001) have defined MVA as "a cumulative measure of the value created by management in excess of the capital invested by shareholders" (p. 42). Wibowo and Berasategui (2008) have also stated that "MVA is a tool in determining how much money investors have made on their investment and the level of value a company has accumulated over time (company's wealth)" (p. 63). Therefore, it is argued that, "MVA depends on the rate of return of a company" (Banerjee, 2000, p. 29).

From another perspective, the relationship between MVA and EVA has frequently been addressed. From a theoretical view of point, the literature refers to a direct association between EVA and MVA. Luber (1996, as cited in Vijayakumar, 2011, p. 23) confirms that "a positive EVA over a period of time will also have an increasing MVA while negative EVA will bring down MVA as the market loses confidence in the competence of a company to ensure a handsome return on the invested capital". In their study, Stern et al. (2001, p. 17) also state that, "there is significant link between EVA growth and growth in MVA". Finally, Aloy and Alfred (2014) have also concluded that, "the best way to maximize MVA is to maximize EVA" (p. 126).

\subsection{Economic Value Added}

EVA currently is considered to be one of most popular performance measures in the field of business. It analyses the performance of firm to show which are truly profitable. Therefore, it is frequently classified as one of the best developed measures to judge whether this objective had been achieved or not. In fact, empirical studies have shown the superiority of EVA over other traditional financial performance measures (Stem, 1990; Stewart, 1994; Lehn \& Makhija, 1996; Sirbu, 2012). According to Stewart (1994) EVA has four main features in general, which include measurement of business performance, management systems, methods of motivation and ways of thinking. Furthermore, Sirbu (2012) argues that, "EVA promises an effective way to manage shareholder value. It aligns management's objectives with those of the shareholders, improves accountability and enables better performance analysis" (p. 305).

From another perspective, the traditional accounting measures have been frequently criticised because of their deficiency in expressing the actual value created by the firm. In this regard, as a financial measure, EVA plays a vital role in adjusting accounting data to reflect the true economic status of the firm. Moreover, EVA overcomes this criticism because it is computed as an excess profit of a firm after accounting for the cost of capital. Consequently, it is the difference between Net Operating Profit after Tax (NOPAT) and the capital charge for both debt and equity. However, being that EVA is at the heart of this study, it is addressed as an independent variable relating to $\mathrm{CSV}$.

\subsection{Traditional Performance Measures}

The use of traditional accounting data for the purpose of evaluating value and performance of firms has been criticised over a long period of time because it is prepared based on generally accepted accounting principles (GAAP), or based on International Accounting Standards (IASs). These principles and standards are then provide an estimation of many figures, in addition to the diversity of applications, which leads to distorted accounting data. 
Over the years, a lot of accounting indicators have been developed to measure the value and performance of economic entities. These traditional performance measures, such as residual income and accounting based returns, have also been criticised because they do not consider the total cost of capital employed and because they fail to assess the genuine economic returns (Chen \& Dodd, 1997; Haque et al., 2004; Shil, 2009; Nakhaei \& Hamid, 2013).

However, despite the variety of measures that could be used to measure and explain the value of a firm and evaluate its performance, researchers have highlighted that, "there is no single accounting measure which explains the variability in the shareholders' wealth" (West \& Worthington, 2001; Rogerson, 1997; Chen \& Dodd, 1997; Lehn \& Makhija, 1996). In this regard, Sharma and Kumar (2010, p. 201) recognise that, "Any financial measures used in assessing firm's performance must be highly correlated with shareholders' wealth and on the other hand should not be subjected to randomness inherent in it". Therefore, the search for substitute measures in accounting and financial fields could be said to have begun three decades ago when modern measures such as EVA, MVA and CSV were born.

However, this study has considered return on assets as a proxy of the accounting measures. ROA is a measure of profitability of the firm in relation to its total assets. It is considered as an independent variable in the current study. In addition, simple regression has been used to test, yearly, the explanatory power of both of EVA and ROA upon the change of measures of CSV, starting from the year 2012.

\subsection{Hypotheses of the Study}

As we discussed in the section on prior studies and the theoretical framework, a positive significant relationship was found, in general, between EVA and CSV. The objective of this study is to address this relationship in JPIF listed on ASE comparing to the return on assets. In addition, this study also aims to address the possible superiority of EVA to ROA in explaining the changes of CSV (for the two measures, CSV-F and MVA) for JPIF over the period 2012-2015. Therefore, the following six hypotheses have been drawn:

H01: EVA positively affects CSV-F for JPIF for each year from 2011 to 2015.

H02: EVA positively affects MVA for JPIF for each year from 2011 to 2015.

H03: ROA positively affects CSV-F for JPIF for each year from 2011 to 2015.

H04: ROA positively affects MVA for JPIF for each year from 2011 to 2015.

H05: EVA is superior to ROA in explaining the changes of CSV-F for JPIF over the period 2012-2015.

H06: EVA is superior to ROA in explaining the changes of MVA for JPIF over the period 2012-2015.

\section{Methodology}

\subsection{The Population and Sample of the Study}

The population of study mainly consists of all the Jordanian industrial firms publicly listed on the ASE during the period 2011-2015. The sample of the study was selected according to two main conditions: 1-the firm should be listed on ASE and continued with normal operations over all years from the beginning of 2011 to the ending of 2015; 2-the availability of all the data required for 6years from 2010 to 2015 . Based on these two conditions, the study sample includes 51 industrial firms from groups of firms ranging annually from 66 firms to 74 firms listed on ASE during the period, as seen in Table 1.

Table 1. Numbers and classification of companies that comprise the study sample

\begin{tabular}{lc}
\hline \multicolumn{1}{c}{ Industrial Sector } \\
\hline Sub-Sectors & Number of companies \\
\hline Pharmaceutical \& Medical Industries & 6 \\
Chemical Industries & 9 \\
Paper and Cardboard Industries & 3 \\
Food and Beverages & 7 \\
Mining \& Extraction Industries & 7 \\
Engineering \& Construction & 7 \\
Electrical Industries & 4 \\
Textiles, Leathers \& Clothing & 5 \\
Other sectors & 3 \\
\hline Total & $\mathbf{5 1}$ \\
\hline
\end{tabular}




\subsection{Collection and Preparation of Data}

For the purposes of this study, we depended on secondary resources to gather data. The data was collected entirely from published annual financial reports. For the purposes of statistical analysis, the data was prepared manually for all the variables, with the exception of two variables-ROA and Debit Ratio-which were taken directly from the reports as computed by the firms. In addition, all the important and applicable accounting adjustments have been taken into account when calculating the invested capital, NOPAT, and hence EVA.

\subsection{Variables Measurement}

Empirical models have been used in this study to assess the relationships between EVA, ROA and CSV. CSV has been measured by two models: Fernandez's model (2001) and MVA model. In addition, capital structure and growth of firm were taken as control variables. However, the variables are defined as follows.

\subsubsection{Economic Value Added}

The economic value added is calculated on an annual basis according to the following formula:

$$
E V A=N O P A T-\left(I C^{*} W A C C\right)
$$

Where: NOPAT is net operating profit after tax, IC is invested capital and WACC is the weighted average cost of capital.

$$
\text { WACC }=\frac{\text { Debts }}{\text { Total Funding }}(\text { Cost of Debt })(1-T)+\frac{\text { Equity }}{\text { Total Funding }}(\text { Cost of Equity })
$$

Where: $\mathrm{T}$ is the tax rate, debts are all interest-bearing debts, total funding is the summation of all interest-bearing debts and ordinary equity, while in this study, the cost of debt is the gross interest expense divided by all interest-bearing debts.

Cost of equity is mostly determined using theCapital Asset Pricing Model(CAPM), as in the following equation:

Where:

$$
r_{i}=r_{f}+\beta\left(r_{m}-r_{f}\right)
$$

$r_{i}$ : The return on risky assets (the cost of equity).

$r_{f}$ : The return on risk-free assets (such as Treasury Bills). In this study, $r_{f}$ is computed based on a 10-year government bond yield.

$r_{m}$ : The return on the stock market (index).

$B$ : Beta is a measure of systemic risk (market risk) and represents, annually, a coefficient of the change of the company's share price compared to the overall market index. Therefore, it consists of the day-to-day fluctuations in a stock's price and is calculated as follows:

\subsubsection{Fernandez Model}

$$
\beta=\frac{\Delta r_{i}}{\Delta r_{m}} * 100
$$

According to Fernandez (2001), CSV can be quantified as follows:

\section{Created shareholder value $=$ Equity market value $x$ (Shareholder return-Ke)}

According to this model,CSV can be computed through the following steps:

1 -Equity market value (capitalisation) $=$ Share's price $x$ the number of shares

2-The Increase of equity market value $(\Delta E)=$ The equity market value $t^{-}$- the equity market value ${ }_{t-1}$

3-Shareholder value added =Increase of equity market value

+ Dividends paid during the year

+Other payments to shareholders (discounts on par value, share buy-backs, ...)

-Outlays for capital increases, exercise (purchase) of stock options and stock warrants

-Conversion of convertible debentures

4-All-shareholder return $=$ Shareholder value added ${ }_{\mathrm{t}} /$ Equity market value $_{\mathrm{t}-1}$

$5-\mathrm{Ke} \quad=$ Cost of capital

\subsubsection{Market Value Added Model}

The market value added has become a popular tool in the financial field after it was initiated by the consulting 
firm Stern Stewart. Young and O'Byrne (2001) hence explain MVA as the difference between the firm's market value (including equity and debt) and the total capital invested in the company. Therefore, in this study, MVA is measured in the following formula:

$$
\text { MVA = Total Market Value-Total Capital }=(\text { MV of Stock }+ \text { MV of Debt }) \text {-Total invested Capital }
$$

Where the MV of stock is the market capitalisation and the MV of debt is market value of debts. However, in Jordan, as it is in many other developing countries, there is no active market for debts where it could receive the market value for the debt. Therefore, to estimate MVA in this study, the book value of debt has been considered as equivalent to the market value of debt. Total invested capital is hence equal to the total book value of debt and equity modified by accounting adjustments.

\subsubsection{Traditional Accounting Measures}

There are many accounting measures traditionally used to assess firm performance. In this regard, the most popular factor is profitability, measured mostly by ROA. In this study, data for this variable has been taken directly from the annual published financial statements for Jordan's publicly listed industrial firms. The formula to calculate this variable is as follow:

$$
R O A=\frac{(\text { Net Income }+ \text { Finance Interests }) * 100}{\text { Total Assets }}
$$

\subsubsection{Control Variables}

Reviewing the literature in the areas such as this study, we could find many variables that affect the value of firm, either positively or negatively, such as profitability, growth, capital structure, firm size, taxes and the investment and cost of capital. This study has considered two factors expected to affect the firm's value positively. These two variables are the growth measured by the average of both total assets growth rate and net sales growth rate and the capital structure measured by the debt ratio.

$$
\begin{gathered}
\text { Debit } \text { Ratio }=\frac{\text { Total liabilities } * 100}{\text { Total Assets }} \\
\text { Total net sales } \text { growth } \text { rate }_{i t}=\frac{\text { Total net } \text { salest } \text { total } \text { net } \text { salest }-1}{\text { total net } \text { salest }-1}
\end{gathered}
$$

\section{Empirical Results}

\subsection{Descriptive Statistics}

The descriptive statistics for the variables used in the study are presented in Table 2. We note that there are no consistent trends in the mean for all variables over the years with the exception of the department ratio. In fact, the changes in these averages have fluctuated from year to year. In general, the best performance for JPIF was in the year 2014, when all three of the variables achieved their best indicators; namely, EVA=852852, ROA=2.86\% and MVA=13007209. The next best year for JPIF was 2012, where the two variables that achieved their best indicators, were CSV-F $=24857265$ and Growth $=3.41 \%$.

For EVA, the worst performance for JPIF was in 2012 (EVA=-936495). In this year, JPIF also reported the lowest CSV-F(CSV-F=20087322), although the lowest CSV measured was reported in 2011 (MVA=6363432). The worst performance for ROA and Growth for JPIF was in the year 2015 , where ROA was- $0.59 \%$ and the growth rate was- $9.66 \%$.

Regarding to the DebtR, the lowest percentage for JPIF was in 2011 (DebtR=34.54\%) and this may be due to the global financial crisis, which ended later that year. After 2011, the external financing part of capital structure increased yearly until it reached its best level in the year 2015 (DebtR=40.02\%).

Table 2. Descriptive statistics for the variables used in the study

\begin{tabular}{cccccccc}
\hline \multirow{2}{*}{ No. } & \multirow{2}{*}{ Variables } & Descriptive & \multicolumn{5}{c}{ Years } \\
\cline { 3 - 7 } & & Statistics & $\mathbf{2 0 1 5}$ & $\mathbf{2 0 1 4}$ & $\mathbf{2 0 1 3}$ & $\mathbf{2 0 1 2}$ & $\mathbf{2 0 1 1}$ \\
\hline \multirow{2}{*}{$1-$} & EVA & Mean & -21491 & 852852 & 398198 & -936495 & 509775 \\
& & SD & 5286172 & 4642256.3 & 6377524 & 7076468 & 5002853 \\
$2-$ & \multirow{2}{*}{ ROA } & Mean & -.0059 & .0286 & .0250 & .0035 & .0023 \\
& & SD & .1184 & .0917 & .0839 & .1042 & .0885 \\
$3-$ & CSV-F & Mean & 23513760 & 24695412 & 24857265 & 20087322 & 20274137 \\
& & SD & 61358326 & 45146381 & 52068492 & 31843162 & 27968701 \\
\hline
\end{tabular}




\begin{tabular}{cccccccc}
\hline $4-$ & MVA & Mean & 11897925 & 13007209 & 12836182 & 7017462 & 6363432 \\
& & SD & 53855621 & 37320789 & 44566935 & 22786261 & 16622536 \\
$5-$ & \multirow{2}{*}{ DebtR. } & Mean & .4002 & .3876 & .3793 & .3754 & .3454 \\
& & SD & .2980 & .2307 & .2228 & .2241 & .2059 \\
\multirow{2}{*}{$6-$} & Growth & Mean & -.0966 & .0318 & .0341 & .0080 & .0178 \\
& & SD & .1668 & .2694 & .2656 & .2589 & .1927 \\
\hline
\end{tabular}

Note. ${ }^{*} \mathrm{CSV}=$ Created Shareholders Value.

With regard to the correlation, there are no fixed accepted rules for describing correlation strength. In this study, the absolute value of correlation depends on the following guidelines: when $0<\mathrm{r}<.30$ the correlation is weak; when $30<r<.70$ the correlation is moderate; and when $r>.70$ the correlation is strong. Based on these rules, Table 3 and Table 4 present, respectively, the strong and moderate Pearson correlations for variables used in the study over the years 2011-2015. The weak relationships between variables have been neglected in this study.

As can be seen in Table 3, all the variables correlate with each other with positive significant relationships in some years. What is notable in Table 3 is that MVA-CSV-F has strong relationships every year. In Table 4, we can also see that most of variables are correlated with moderately positive significant relationships, with the exception of DebtR, which has a negative significant relationship with EVA in two years (2011 and 2015) and ROA in years 2011, 2012 and 2015.

Table 3. Summary of Pearson correlation for the strong correlation coefficients between variables over the years 2011-2015

\begin{tabular}{lccccc}
\hline \multirow{2}{*}{\multicolumn{1}{c}{ Variables }} & \multicolumn{5}{c}{ Strong Correlations } \\
\cline { 2 - 5 } & $\mathbf{2 0 1 5}$ & $\mathbf{2 0 1 4}$ & $\mathbf{2 0 1 3}$ & $\mathbf{2 0 1 2}$ & $\mathbf{2 0 1 1}$ \\
\hline EVA-CSV-F & $.866^{* *}$ & $.851^{* *}$ & & \\
EVA-MVA & $.804^{* *}$ & $.822^{* *}$ & & & $.727^{* *}$ \\
EVA-ROA & & & & $.839^{* *}$ & $.829^{* *}$ \\
MVA-CSV-F & $.962^{* *}$ & $.939^{* *}$ & $.962^{* *}$ & \\
\hline
\end{tabular}

Note. $* *$ Correlation is significant at the 0.01 level (2-tailed). *Correlation is significant at the 0.05 level (2-tailed).

Table 4. Summary of Pearson correlation for the moderate correlation coefficients between variables over the years 2011-2015

\begin{tabular}{|c|c|c|c|c|c|}
\hline \multirow{2}{*}{ Variables } & \multicolumn{5}{|c|}{ Moderate Correlations } \\
\hline & 2015 & 2014 & 2013 & 2012 & 2011 \\
\hline EVA-CSV-F & & & $.632^{* *}$ & & $.488^{* *}$ \\
\hline EVA-MVA & & & $.629^{* *}$ & $.417^{* *}$ & $.419^{* *}$ \\
\hline EVA-ROA & $.679^{* *}$ & $.572^{* *}$ & $.580^{* *}$ & $.453^{* *}$ & \\
\hline EVA-DebtR & $-.383^{* *}$ & & & & $-.328^{*}$ \\
\hline EVA-Growth & $.365^{* *}$ & & & & \\
\hline MVA-CSV-F & & & & & \\
\hline MVA-ROA & $.331^{*}$ & $.392^{* *}$ & $.388^{* *}$ & & $.380^{* *}$ \\
\hline ROA-CSV-F & $.436^{* *}$ & $.428^{* *}$ & $.421^{* *}$ & $.421^{* *}$ & $.305^{*}$ \\
\hline ROA-DebtR & $-.614^{* *}$ & & & $-.351^{*}$ & $-.374^{* *}$ \\
\hline ROA-Growth & $.508^{* *}$ & $.473^{* *}$ & & $.301^{*}$ & \\
\hline
\end{tabular}

Note. **Correlation is significant at the 0.01 level (2-tailed). *Correlation is significant at the 0.05 level (2-tailed).

\subsection{Testing and Discussion of Hypotheses}

In this study, the multiple regression was used to test, independently, the influence of both EVA and ROA on each of the measures of CSV adopted in this study. In each case, the regression was controlled by two explanatory variables: the debt ratio and the growth rate of the firm.

This procedure has been performed separately for all years from 2011 to 2015 for each of the hypotheses H01-H04. In addition, a simple regression was used to test, yearly, the explanation power (i.e. $\mathrm{R}^{2}$ ) of both EVA and ROA in terms of the change of measures of CSV starting from the year 2012 for each of the hypotheses H05-H06. The results of testing these hypotheses HO1-HO6 are as follow: 


\section{H01: EVA positively affects CSV-F for each year from 2011 to2015.}

This hypothesis has been drawn to determine whether EVA affects the CSV measured positively by the Fernandez model in JPIF for each year from 2011 to2015. A multiple regression, as in equation1, was run to predict CSV-F from EVA, the debt ratio and the growth of firms for all the years2011-2015.

$$
C S V-F=\alpha i+\beta 1 E V A+\beta 2 D e b t R+\beta 3 \text { Growtht }+e
$$

Table 5 presents the results of testing of hypothesis $H 01$ in the years 2011-2015.These variables were, jointly, found in all years statistically significantly predicted CSV-F. In addition, all three variables added, in all the years, statistically significant in relation to the prediction, $\mathrm{p} \leq .021$. At this level of detail, it is found that EVA significantly affects CSV-F in all the years concerned. Therefore, we accept the hypothesis H01: EVA positively affects firm value measured by CSV-F.

With respect to explanatory variables, the debt ratio is found to affect CSV-F significantly in 2015. The results of this study are consistent with Imanzadeh (2014) who found a direct link between EVA and CSV-F. Consequently, these results may refer to the hypothesis that EVA properly measures wealth creation in terms of CSV-F, which makes it inconsistent with the studies conducted by Fernandez (2001, 2002), ElMir and Seboui (2006) and Nekounam et al. (2013).

Table 5. Multiple regression results for the effect of EVA on CSV-F for the years2011-2015 (controlled by the debt ratio and growth of firms)

\begin{tabular}{|c|c|c|c|c|c|c|c|c|c|}
\hline \multirow{2}{*}{ Years } & \multirow{2}{*}{ Variables } & \multicolumn{3}{|c|}{ Model Summary } & \multicolumn{2}{|c|}{ ANOVA } & \multicolumn{3}{|c|}{ Coefficients } \\
\hline & & $\mathbf{R}$ & $\mathbf{R}^{2}$ & Adj. $R^{2}$ & $\mathbf{F}$ & Sig. & B & $\mathbf{t}$ & Sig. \\
\hline \multirow[t]{3}{*}{2015} & DebtR & & & & & & 58688409 & 4.350 & .000 \\
\hline & Growth & .910 & .829 & .818 & 75.862 & .000 & -31448752 & -1.316 & .195 \\
\hline & EVA & & & & & & 11.684 & 14.608 & .000 \\
\hline \multirow[t]{3}{*}{2014} & DebtR & & & & & & 18229123 & 1.230 & .225 \\
\hline & Growth & .860 & .739 & .722 & 44.386 & .000 & -13897274 & -1.104 & .275 \\
\hline & EVA & & & & & & 8.539 & 11.503 & .000 \\
\hline \multirow[t]{3}{*}{2013} & DebtR & & & & & & 19331660 & .725 & .472 \\
\hline & Growth & .637 & .406 & .368 & 10.703 & .000 & 4068408 & .179 & .859 \\
\hline & EVA & & & & & & 5.218 & 5.500 & .000 \\
\hline \multirow[t]{3}{*}{2012} & DebtR & & & & & & -12999547 & -1.025 & .311 \\
\hline & Growth & .435 & 190 & .137 & 3.585 & .021 & 13728683 & 1.268 & .211 \\
\hline & EVA & & & & & & 1.365 & 3.082 & .003 \\
\hline \multirow[t]{3}{*}{2011} & DebtR & & & & & & 9918251 & .554 & .582 \\
\hline & Growth & .523 & .273 & .227 & 5.892 & .002 & -25640337 & -1.379 & .174 \\
\hline & EVA & & & & & & 3.095 & 4.112 & .000 \\
\hline
\end{tabular}

Note. Dependent Variable:CSV-F.

\section{H02: EVA positively affects MVA for each year from 2011 to 2015.}

This hypothesis has been drawn to determine whether EVA affects the MVA positively in JPIF for each year from 2011 to 2015. Thus, as in equation 2, a multiple regression was run to predict MVA from EVA, the debt ratio and growth of firms for each of the years 2011-2015.

$$
M V A=\alpha i+\beta 1 E V A+\beta 2 D e b t R+\beta 3 \text { Growtht }+e
$$

Table 6 presents the results of testing of hypothesis HO2 in years 2011-2015. These variables, jointly, were found in all years statistically significantly predicted MVA. In addition, all three variables added, in all years, statistically significantly to the prediction, $p \leq .022$. At this level of detail, it is found that EVA significantly affects MVA in all years. Therefore, we accept the hypothesis $H 02$, EVA also affects firm value positively measured by MVA. These results are inconsistent with the study carried by Aloy and Alfred (2014) who found no association between EVA and MVA. With respect to explanatory variables, we can see that the debt ratio is found significantly affect MVA in two years, 2015 and 2004, whereas the growth rate found to be significantly affect MVA in the year 2011. Generally, the result of present study is consistent with a lot of studies carried out in this area. Actually, we could say that MVA can be well predicted by EVA. 
Table 6. Multiple regression results for the effect of EVA on MVA for the years 2011-2015 (controlled by the debt ratio and growth of firms)

\begin{tabular}{|c|c|c|c|c|c|c|c|c|c|}
\hline \multirow{2}{*}{ Years } & \multirow{2}{*}{ Variables } & \multicolumn{3}{|c|}{ Model Summary } & \multicolumn{2}{|c|}{ ANOVA } & \multicolumn{3}{|c|}{ Coefficients } \\
\hline & & $\mathbf{R}$ & $\mathbf{R}^{2}$ & Adj. $R^{2}$ & $\mathbf{F}$ & Sig. & B & $t$ & Sig. \\
\hline \multirow[t]{3}{*}{2015} & DebtR & & & & & & 75943842 & 6.059 & .000 \\
\hline & Growth & .899 & .808 & .796 & 66.030 & .000 & -29279095 & -1.319 & .194 \\
\hline & EVA & & & & & & 10.165 & 13.680 & .000 \\
\hline \multirow[t]{3}{*}{2014} & DebtR & & & & & & 40853725 & 3.350 & .002 \\
\hline & Growth & .861 & .742 & .725 & 44.979 & .000 & -9053213 & -.875 & .386 \\
\hline & EVA & & & & & & 7.042 & 11.532 & .000 \\
\hline \multirow[t]{3}{*}{2013} & DebtR & & & & & & 37165529 & 1.662 & .103 \\
\hline & Growth & .656 & .430 & .394 & 11.842 & .000 & 9031532 & .474 & .637 \\
\hline & EVA & & & & & & 4.501 & 5.661 & .000 \\
\hline \multirow[t]{3}{*}{2012} & DebtR & & & & & & 9093651 & .660 & .512 \\
\hline & Growth & .428 & .183 & .131 & 3.520 & .022 & 5065269 & .431 & .668 \\
\hline & EVA & & & & & & 1.379 & 3.161 & .003 \\
\hline \multirow[t]{3}{*}{2011} & DebtR & & & & & & 18030204 & 1.774 & .082 \\
\hline & Growth & .580 & .337 & .295 & 7.962 & .000 & -29585459 & -2.803 & .007 \\
\hline & EVA & & & & & & 1.904 & 4.455 & .000 \\
\hline
\end{tabular}

Note. Dependent Variable:MVA.

\section{H03: ROA positively affects CSV-F for each year from 2011 to2015.}

This hypothesis has been drawn to determine whether ROA affects CSV-F positively in JPIF for each year from2011 to2015. As in equation 3, a multiple regression was run to predict CSV-F from ROA, the debt ratio and the growth of firms for all the years 2011-2015.

$$
C S V-F=\alpha i+\beta 1 R O A+\beta 2 D e b t R+\beta 3 \text { Growtht }+e
$$

Table 7 presents the results of testing hypothesis $H 05$ in the years 2011-2015. These variables were jointly found in all years where CSV-F was predicted to be statistically significant. In addition, all three variables added, in all years, statistical significance to the prediction $p<.05$, with the exception of 2011. In 2011, the variables did not add up to be statistically significant to the prediction>.05; $(\mathrm{p}=.066)$. At this level of details, ROA was found to affect CSV-F significantly in all the years. Therefore, we accept the hypothesis H03. In addition, ROA also affects CSV-F positively. With respect to the control variables, neither of the two variables, 'DebtR' and 'growth' were found to be affecting CSV-F significantly in all the years concerned. However, the researcher has not found any study conducted directly on the relationship between ROA and CSV-F, although this does not mean the absence of such studies.

Table 7. Multiple regression results for the effect of ROA on CSV-F for the years2011-2015 (controlled by debt ratio and growth of firms)

\begin{tabular}{|c|c|c|c|c|c|c|c|c|c|}
\hline \multirow{2}{*}{ Years } & \multirow{2}{*}{ Variables } & \multicolumn{3}{|c|}{ Model Summary } & \multicolumn{2}{|c|}{ ANOVA } & \multicolumn{3}{|c|}{ Coefficients } \\
\hline & & $\mathbf{R}$ & $\mathbf{R}^{2}$ & Adj. $\mathbf{R}^{2}$ & $\mathbf{F}$ & Sig. & $\mathbf{B}$ & $\mathbf{t}$ & Sig. \\
\hline \multirow[t]{3}{*}{2015} & DebtR & & & & & & 62326856 & 1.862 & .069 \\
\hline & Growth & .496 & .246 & .198 & 5.113 & .004 & -15313972 & -.279 & .781 \\
\hline & ROA & & & & & & 333351746 & 3.481 & .001 \\
\hline \multirow[t]{3}{*}{2014} & DebtR & & & & & & 12379583 & .477 & .636 \\
\hline & Growth & .477 & .228 & .179 & 4.622 & .006 & -39824719 & -1.623 & .111 \\
\hline & ROA & & & & & & 273386342 & 3.686 & .001 \\
\hline \multirow[t]{3}{*}{2013} & DebtR & & & & & & 11185118 & .358 & .722 \\
\hline & Growth & .424 & .180 & .128 & 3.440 & .024 & 6840629 & .251 & .803 \\
\hline & ROA & & & & & & 258774010 & 2.995 & .004 \\
\hline \multirow[t]{3}{*}{2012} & DebtR & & & & & & -2989845 & -.149 & .882 \\
\hline & Growth & .425 & .181 & .128 & 3.453 & .024 & -7100293 & -.417 & .679 \\
\hline & ROA & & & & & & 131638367 & 2.935 & .005 \\
\hline \multirow[t]{3}{*}{2011} & DebtR & & & & & & 6018431 & .303 & .763 \\
\hline & Growth & .375 & .140 & .086 & 2.560 & .066 & -34992296 & -1.592 & .118 \\
\hline & ROA & & & & & & 135796401 & 2.651 & .011 \\
\hline
\end{tabular}

Dependent Variable:CSV-F. 


\section{H04: ROA positively affects MVA for each year from 2011 to2015.}

This hypothesis has been drawn to determine whether ROA affects MVA positively in JPIF for each year from 2011 to2015. As in equation4, a multiple regression was run to predict MVA from ROA, the debt ratio and the growth of the firms concerns for each year 2011-2015.

$$
M V A=\alpha i+\beta 1 R O A+\beta 2 D e b t R+\beta 3 \text { Growtht }+e
$$

Table 8 presents the results of testing hypothesis $H 04$ in the years 2011-2015. These variables were found jointly in all the years statistically significantly where MVA was predicted. In addition, all the three variables added were statistically significantly to the prediction, $\mathrm{p}<.05$, in all the years concerned. At this level of details, ROA is found to affect MVA significantly in all the years concerned. Consequently, the results confirm Hypothesis $H 04$ and we accept this hypothesis; ROA positively affect firm value measured by MVA. These results are consistent with the conclusion of Roze et al. (2013), which indicated that financial criteria such as ROA are in direct linear and significant relationship with MVA. With respect to the control variables, the debt ratio was found to affect the MVA significantly in the year 2015, whereas the growth rate is found to affect MVA significantly in the year 2011. However, mixed results were found regarding the relationship between EVA, accounting measures and creating shareholders.

Table 8. Multiple regression results for the effect of ROA on MVA for the years2011-2015 (controlled by debt ratio and growth of firms)

\begin{tabular}{|c|c|c|c|c|c|c|c|c|c|}
\hline \multirow{2}{*}{ Years } & \multirow{2}{*}{ Variables } & \multicolumn{3}{|c|}{ Model Summary } & \multicolumn{2}{|c|}{ ANOVA } & \multicolumn{3}{|c|}{ Coefficients } \\
\hline & & $\mathbf{R}$ & $\mathbf{R}^{2}$ & Adj. $R^{2}$ & $\mathbf{F}$ & Sig. & B & $\mathbf{T}$ & Sig. \\
\hline \multirow[t]{3}{*}{2015} & DebtR & & & & & & 76305713 & 2.551 & .014 \\
\hline & Growth & .468 & .219 & .169 & 4.382 & .008 & -11478797 & -.234 & .816 \\
\hline & ROA & & & & & & 276789034 & 3.234 & .002 \\
\hline \multirow[t]{3}{*}{2014} & DebtR & & & & & & 35777498 & 1.665 & .102 \\
\hline & Growth & .477 & .227 & .178 & 4.610 & .007 & -29993022 & -1.478 & .146 \\
\hline & ROA & & & & & & 222692412 & 3.631 & .001 \\
\hline \multirow[t]{3}{*}{2013} & DebtR & & & & & & 29426282 & 1.096 & .279 \\
\hline & Growth & .418 & .175 & .122 & 3.325 & .027 & 13147065 & .562 & .577 \\
\hline & ROA & & & & & & 204129711 & 2.752 & .008 \\
\hline \multirow[t]{2}{*}{2012} & DebtR & & & & & & 14548244 & 1.003 & .321 \\
\hline & Growth & .403 & .162 & .109 & 3.036 & .038 & -1211836 & -.098 & .922 \\
\hline \multirow[t]{4}{*}{2011} & ROA & & & & & & 94893281 & 2.925 & .005 \\
\hline & DebtR & & & & & & 16807078 & 1.500 & .140 \\
\hline & Growth & .473 & .224 & .174 & 4.516 & .007 & -36914384 & -2.974 & .005 \\
\hline & ROA & & & & & & 91928573 & 3.177 & .003 \\
\hline
\end{tabular}

H05: EVA is superior to ROA in explaining the changes of CSV-F for JPIF over the period 2012-2015.

This hypothesis has been drawn to determine whether EVA is superior to ROA in explaining the changes of CSV-F for JPIF over the period 2012-2015. As in equations 5 and 6, a simple regression was run to predict the changes of CSV-F for the four years 2012-2015.

$$
\begin{aligned}
& \Delta C S V-F_{t}=E V A_{t-1}+e \\
& \Delta C S V-F_{t}=R O A_{t-1}+e
\end{aligned}
$$

Table 9 presents the results of testing hypothesis H05 in the years 2012-2015. Here, EVA is found to be statistically significantly in predicting the changes of CSV-F for JPIF over the period 2012-2015. In all the years, it is added to be statistically significantly to the prediction, $\mathrm{p}<.001$. Thus, in relation to ROA, it is found to be statistically significantly in predicting the changes of CSV-F for JPIF in two years, 2012 and 2013, and it is added, in these two years, to be statistically significantly to the prediction, $\mathrm{p}<.001$.

Taking a closer look at Table 9, we can see that EVA demonstrates explanatory powers in the years 2012, 2013 and 2015, with much more done by ROA. What is notable is that the two variables had a same explanation power in the years 2014 for EVA and 2013 for ROA. In general, these results do support the hypothesis that EVA is superior to ROA in explaining the changes of CSV-F for JPIF over the period 2012-2015. Therefore, it could be said that the results confirm the hypothesis $H 05$. 
Table 9. Simple regression results for the effect of each of EVA and ROA on the changes to CSV-F for the years 2012-2015

\begin{tabular}{lcccccc}
\hline \multirow{2}{*}{ Variables } & \multirow{2}{*}{ Years } & \multicolumn{3}{c}{ Model Summary } & \multicolumn{2}{c}{ ANOVA } \\
\cline { 3 - 7 } & & $\mathbf{R}$ & $\mathbf{R}^{\mathbf{2}}$ & Adj. $^{\mathbf{2}}$ & F & Sig. \\
\hline EVA- CHCSV-F & 2015 & .740 & .548 & .539 & 59.470 & .000 \\
& 2014 & .471 & .222 & .206 & 13.998 & .000 \\
& 2013 & .775 & .600 & .592 & 73.627 & .000 \\
& 2012 & .531 & .282 & .268 & 19.283 & .000 \\
\hline ROA-CHCSV-F & 2015 & .107 & .011 & -.009 & .569 & .454 \\
& 2014 & .043 & .002 & -.019 & .090 & .766 \\
& 2013 & .471 & .222 & .206 & 13.991 & .000 \\
& 2012 & .400 & .160 & .143 & 9.315 & .000 \\
\hline
\end{tabular}

\section{H06: EVA is superior to ROA in explaining the changes of MVA for JPIF over the period 2012-2015.}

This hypothesis has been drawn to determine whether EVA is superior to ROA in explaining the changes of MVA for JPIF over the period 2012-2015. As in equations 7 and 8, a simple regression was run to predict the changes of MVA for four years 2012-2015.

$$
\begin{aligned}
& \triangle M V A_{t}=E V A_{t-1}+e \\
& \triangle M V A_{t}=R O A_{t-1}+e
\end{aligned}
$$

Table 10 resents the results of testing hypothesis HO6 in the years 2012-2015. EVA is found to be statistically significant in predicting the changes of MVA for JPIF over the period 2012-2015 while, it is added, in all the years, to be statistically significant to the prediction, $\mathrm{p}<.001$. ROA is then found to be statistically significant in predicting the changes of CSV-F for JPIF in two years, 2012 and 2013, and it is added, in these two years, to be statistically significantly to the prediction, $\mathrm{p} \leq .018$.

As can we see in Table 10, EVA demonstrates explanatory powers in all the years, much more than done by ROA. These results strongly support the superiority of EVA to ROA in explaining the changes of MVA for JPIF over the period 2012-2015. Therefore, it could be said that the results succeed in confirming the hypothesis $H 06$. These results are inconsistent with the studies carried out by Biddle et al. (1997), Clinton and Chen (1998), Ramana (2005) and Kim (2006).

Table 10. Simple regression results for the effect of each of EVA and ROA on the changes of MVA for the years2012-2015

\begin{tabular}{lcccccc}
\hline \multirow{2}{*}{ Variables } & Years & \multicolumn{3}{c}{ Model Summary } & \multicolumn{2}{c}{ ANOVA } \\
\cline { 3 - 7 } EVA-CHMVA & $\mathbf{R}$ & $\mathbf{R}^{\mathbf{2}}$ & Adj. $\mathbf{R}^{\mathbf{2}}$ & F & Sig. \\
& 2015 & .668 & .446 & .435 & 39.525 & .000 \\
& 2014 & .507 & .257 & .242 & 16.920 & .000 \\
& 2013 & .529 & .280 & .266 & 19.076 & .000 \\
& 2012 & .587 & .344 & .331 & 25.708 & .000 \\
\hline \multirow{2}{*}{ ROA-CHMVA } & 2015 & .191 & .037 & .017 & 1.860 & .179 \\
& 2014 & .084 & .007 & -.013 & .348 & .558 \\
& 2013 & .357 & .127 & .109 & 7.147 & .010 \\
& 2012 & .331 & .109 & .091 & 6.012 & .018 \\
\hline
\end{tabular}

\section{Conclusion}

These days, the main objectives of firms have shifted to the creation of value and achieving satisfactory returns through increasing profitability and shareholders' wealth. There are many indicators that can be used to measure CSV, including CSV-F and MVA. On the other hand, the measurement and evaluation of value and the performance of firms have become a very important concern. Therefore, the firm should choose the use of a performance measure that could lead to maximising shareholder returns and, consequently, the value of the firm.

This study has two main objectives. The first is to address the relationship between EVA and CSV in JPIF listed on the ASE, comparing it to the traditional accounting measures represented by ROA. We have found that both EVA and ROA have a positive and significant influence on CSV measured by Fernandez Model and MVA for each of the years2011-2015.Therefore, the results confirm the general hypotheses that these two measures affect 
CSV positively. With respect to the explanatory variables used in the study (i.e. the debt ratio and growth rate), we have found that the effects of these variable differ from one measure of CSV to another and from one year to another. Nonetheless, we can say that the explanatory variables were found, jointly, in all years to be statistically significant in predicting CSV for all measures with the exception of ROA-CSVF in the year 2011.

The second objective of this study has been to address the possible superiority of EVA to ROA in explaining the changes of CSV for JPIF over the period 2012-2015. With regard to CSV-F, EVA has demonstrated explanatory powers in the years 2012, 2013 and 2015 much more than that performed by ROA, although the two variables had the same explanatory power in the years 2014 for EVA and 2013 for ROA. In general, these results support the superiority of EVA to ROA in explaining the changes of CSV-F for JPIF over the period 2012-2015. With regard to MVA, ROA was found to be statistically significant in predicting the changes of CSV-F for JPIF in two years; 2012 and 2013, whereas EVA showed explanatory powers in all the years, to a much greater extent than ROA. This strongly supports the superiority of EVA to ROA in explaining the changes of MVA for JPIF over the period 2012-2015.

The study revealed that CSV is influenced by EVA and ROA, both of which are utilised in this study. In general, the superiority of EVA in predicting and evaluating the CSV can now be taken in a conclusive and positive light compared to ROA. Summing up then, the results of this study suggest that one financial measure cannot be enough to measure neither the created shareholders value nor the performance of firms.

JPIF can get a handle on the measurement of created shareholders value using a combination of two main models, the Fernandez Model and MVA. In addition, for the purpose of performance evaluation, JPIF can also use a combination of the two main indicators, EVA and ROA. Up until now, there have been no regulations in Jordan to compute and disclose these measures in the public firms. Therefore, this study is highly recommended, JPIF is to give more attention to the use of modern indicators, especially CSV, MVA and EVA, in assessing and evaluating their value and performance.

\section{Limitations}

This study has utilised a limited number of measures to show the relationships between CSV and performance measurement. Different measures could be affecting such relations, either positively or negatively. Therefore, the use of other measures has been suggested to confirm the relationships between the variables. In addition, the sample of the study only contains the industrial firms listed in ASE. We would hence suggest the inclusion of the other industries in future studies.

\section{References}

Abdoli, M., Shurvarzi, M., \& Farokhad, A. D. (2012). Economic Value Added vs. Accounting Residual Income; Which One Is a Better Criterion for Measurement of Created Shareholders Value? World Applied Sciences Journal, 17(7), 874-881.

Aloy, N. J., \& Alfred, M. (2014). The Association between Economic Value Added, Market Value Added and Leverage. International Journal of Business and Management, 9(10), 126-133.

Bahadur, S. K., \& Deb, B. C. (2013). Economic Value Added (EVA): A Better Performance Indicator- The Case Study of Square Pharmaceuticals Limited. Journal of Business Studies, 34(2), 233-241.

Banerjee, A. (2000). Linkage between Economic Value Added and Market Value: An Analysis. Vikalpa, 25(3), 23-36. https://doi.org/10.1177/0256090920000304

Bao, B. H., \& Bao, D. H. (1999). The Association between Firm value and Economic Value Added. Indian Accounting Review, 3(2), 161-164.

Bhasin, M. L. (2013). Economic value added and shareholders' wealth creation: The portrait of a developing Asian country. International Journal of Finance and Accounting, 2(4), 185-198. https://doi.org/10.1504/ijmfa.2013.053208

Bhasin, M., \& Shaikh, J. M. (2013). Economic value added and shareholders' wealth creation: The portrait of a developing Asian country. International Journal of Managerial and Financial Accounting, 5(2), 107-137. https://doi.org/10.1504/IJMFA.2013.053208

Biddle, G. C., Bowen, R. M., \& Wallace, J. S. (1997). Does EVA beat earnings? Evidence on associations with stock returns and firm values. Journal of Accounting and Economics, 24(3), 301-336. http://dx.doi.org/10.1016/S0165-4101(98)00010-X

Bierman, Jr. H. (1990). A review of Alfred Appaport's creates shareholder value. Journal of Management 
Accounting Research, 2, 140-154.

Brigham, E. F., \& Ehrhardt, M. C. (2014). Financial Management: Theory and Practice (14th ed.). South-Western, USA.

Business Dictionary. (2016). Shareholder value approach. Retrieved December 2, 2016, from http://www.businessdictionary.com/definition/shareholder-value-approach.html

Chen, S., \& Dodd, J. L. (1997). Economic Value Added: An Empirical Examination of a New Performance Measure. Journal of Managerial Issues, 9(3), 301-336. Retrieved from http://www.jstor.org/stable/40604150

CIMA. (2004). Maximizing shareholder value achieving clarity in decision-making. Technical Report, The Chartered Institute of Management Accountants, London, UK.

Clinton, B. D., \& Chen, S. (1998). Do new performance measures measure up? Management Accounting, 80(4), 38-43.

DeWet, J. HvH. (2005). EVA versus Traditional Accounting Measures of Performance as Drivers of Shareholder Value-A Comparative Analysis. Meditari Accountancy Research, 13(2), 1-16. http://dx.doi.org/10.1108/10222529200500009

ElMir, A., \& Seboui, S. (2006). Corporate governance and earnings management and the relationship between economic value added and created shareholder value. Journal of Asset Management, 7(3), $242-254$. http://dx.doi.org/10.1057/palgrave.jam.2240216

Erasmus, P., \& Scheepers, R. (2008). The Relationship between Entrepreneurial Intensity and Shareholder Value Creation. Managing Global Transitions, 6(3), 229-256.

Farahani, Z., Mehri, M. G., \& Pooya, M. R. K. (2016). The Effect of Free Cash Flows on the Evidence of Earnings Management in Enterprises Listed on the Tehran Stock Exchange. International Research Journal of Applied and Basic Sciences, 10(5), 602-609.

Fernandez, P. (2001). Shareholder Value Creators and Shareholder Value Destroyers in USA: Year 2000. SSRN Electronic Journal. http://dx.doi.org/10.2139/ssrn.272252

Fernandez, P. (2002). A Definition of Shareholder Value Creation. Research Paper No. 448, IESE, University of Navarra.

Fernandez, P., \& Reinoso, L. (2003). Shareholder Value Creation and Shareholder Value destroyers in USA-Year 2002. Working Paper No. 501, CIIF-International Center for Financial Research, IESE Business School, University of Navarra.

Ghanbari, A. M., \& More, V. (2007). The Relationship between Economic Value Added and Market Value Added: An Empirical Analysis in Indian Automobile Industry. The IUP Journal of Accounting Research and Audit Practices, 6(3), 7-22. Retrieved from http://citec.repec.org/rss/icficfjarv_06_y_2007_i_3_p_7-22.xml

Grant, J. L. (1996). Foundations of EVATM for Investment Managers. The Journal of Portfolio Management, 23(1), 41-45. http://dx.doi.org/10.3905/jpm.1996.409573

Hall, J. H. (1998). The agency problem, agency cost and proposed solutions there to: A South African perspective. Meditari Accountancy Research, 6(2), 144-161.

Haque, M., Akter, M., \& Shil, N. C. (2004). Value-Based Measure: An Application of EVA in Small Manufacturing Company in Bangladesh. Retrieved from http://mpra.ub.uni-muenchen.de/7711/

Imanzadeh, P. (2014). Corporate governance and the relationship between EVA and created shareholder value. Applied Mathematics in Engineering, Management and Technology, 2(3), 94-102.

Jensen, M. C. (2002). Value Maximization, Stakeholder Theory, and the Corporate Objective Function. Business Ethics Quarterly, 12(2), 235-56. Retrieved from http://www.jstor.org/stable/3857812

Kaur, M., \& Narang, S. (2008). Economic value added reporting and corporate performance: A study of Satyam computer services Ltd. The ICFAI Journal of Accounting Research, 7(2), 40-52.

Kim,W. G. (2006). EVA and traditional accounting measures: Which metric is a better predictor of market value of hospitality companies? Journal of Hospitality \& Tourism Research, 30(1), 34-49. https://doi.org/10.1177/1096348005284268

Kramer, J. K., \& Peters, J. R. (2001). An Interindustry Analysis of Economic Value Added as a Proxy for Market 
Value Added. Journal of Applied Finance, 11(1),41-49.

Lehn, K., \& Makhija, A. K. (1996). EVA and MVA: As Performance Measures and Signals for Strategic Change. Strategy and Leadership, 24(3), 34-38. http://dx.doi.org/10.1108/eb054556

Luber, R. B. (1996). Who are the real wealth creators. Fortune, 2-3.

Madhavi, E., \& Prasad, M. S. V. (2015). An Empirical Study of Economic Value-Added and Market Value-Added of Selected IndianFMCG Companies. The IUP Journal of Accounting Research \& Audit Practices, 14(3), 49-65.

Maham, K., Ali Asghar, F. Z., \& Javad, H. (2008). Free cash flow. Knowledge and Research on Accounting, (13), 30-37.

Maimako, S. S., \& Oladele, K. O. (2012). Impact of Corporate Restructuring on Value Creation in the Nigerian Banking Industry. SDMIMD Journal of Management, 3(2), 77-96.

Monks, R. A. G., \& Minnow, N. (2011). Corporate Governance (5th ed.). JohnWiley \& Sons, Inc., USA.

Nakhaei, H. (2016). Market value added and traditional accounting criteria: Which measure is a best predictor of stock return in Malaysian companies? Iranian Journal of Management Studies (IJMS), 9(2), 433-455.

Nakhaei, H., \& Hamid, N. I. N. B. (2013). The Relationship between Economic Value Added, Return on Assets, and Return on Equity with Market Value Added in Tehran Stock Exchange (TSE). Proceedings of Global Business and Finance Research Conference, 28-29 October, 2013, Howard Civil Service International House, Taipei, Taiwan.

Nekounam, J., Sotudeh, R., \& Kohandel, Z. (2013). Explain the relationship between corporate governance on economic value-added (EVA) and created shareholder value (CSV). Life Science Journal, 10(2), 67-73.

Pandya, B. (2016). Impact of financial leverage on market value added: Empirical evidence from India. Journal of Entrepreneurship, Business and Economics, 4(2), 40-58.

Panigrahi, S. K., Zainuddin, Y., \& Azizan, N. A. (2014). Comparing Traditional and Economic Performance Measures for Creating Shareholders Value: A Perspective from Malaysia. International Journal of Academic in Accounting, Finance and Management Sciences, 4(4), 280-289.

Paula, D. A., \& Elena, D. C. (2009). EVA versus traditional accounting measures of performance as drivers of shareholder value - A comparative analysis (pp. 53-63). Retrieved from http://www.upm.ro/proiecte/EEE/Conferences/papers/S309.pdf

Pinto, T. C., \& Santos, M. C. (2011). An analysis of the correlation between EVA® and MVA®: The Case of a NYSE Euronext Lisbon Listed Company. Global Journal of International Business Research, 4(4), 69-79.

Pourali, M. R., \& Roze, Z. (2013). The Relationship between Market Value Added with Refined Economic Value Added and Performance Accounting Criteria in the Firms listed in the Tehran Stock Exchange. International Research Journal of Applied and Basic Sciences, 4(6), 1636-1645.

Ramana, D. V. (2005). Market Value Added and Economic Value Added: Some Empirical Evidence. $8^{\text {th }}$ Capital Markets Conference, Indian Institute of Capital Markets Paper. https://doi.org/10.2139/ssrn.871404

Rappaport, A. (1986). Creating Shareholder Value: The New Standard for Business Performance. NewYork: FreePress.

Rogerson,W. (1997). International cost allocation and managerial investments incentives: A theory explaining the use of Economic Value Added as Performance Measure. Journal of Political Economy, 105(4), 770-775.

Roze, Z., Meshki, M., \& Pourali, M. R. (2013). A Study of the Relationship between Economic Criteria and Performance Evaluation Accounting with Market's Value added in the Firms Listed in the Tehran Stock Exchange. Research Journal of Recent Sciences, 2(7), 31-36.

Saha, S. S., \& Roy, M. N. (2015). Performance Measurement and Shareholder Value Creation in Indian Computer Software Industry: An Empirical Analysis. Information and Knowledge Management, 5(6), 74-84.

Sakthivel, N. (2011). Shareholders' Value in Indian Pharmaceutical Industry: An Empirical Analysis. Indian Journal of Commerce \& Management Studies, 2(1), 87-99.

Sharma, A. K., \& Kumar, S. (2010). Economic Value Added(EVA)-Literature Review and Relevant Issues. International Journal of Economics and Finance, 2(2), 200-220. https://doi.org/10.5539/ijef.v2n2p200 
Sharma, A. K., \& Kumar, S. (2012). EVA Versus Conventional Performance Measures-Empirical Evidence from India. Paper presented at the ASBBS Annual Conference, Las Vegas.

Shil, N. C. (2009). Performance measures: An application of economic value added. International Journal of Business and Management, 4(3), 169-177. https://doi.org/10.5539/ijbm.v4n3p169

Sichigea, N., \& Vasilescu, L. (2015). Economic value added and market value added-modern indicators for assessment the firm's value. Annals of 'Constantin Brancusi' University of Targu-Jiu, Economy Series. 2015 Special Iss. ECO-TREND 2015, Performance, Competitiveness, Creativity, pp. 488-493.

Sirbu, A. (2012). Economic value added (EVA) approach in Russia: Concepts, approaches, instruments. Review of International Comparative Management, 13(2), 305-312. Retrieved from http://EconPapers.repec.org/RePEc:rom:rmcimn:v:13:y:2012:i:2:p:305-312

Smith, H. J. (2003). The Shareholders vs. Stakeholders Debate. MIT Sloan Management Review, 44(4), 85-90.

Stem, J. M. (1990). One way to build value in your firm, a la Executive Compensation. Financial Executive, 6(6), $51-54$.

Stern, J. M., Shiely, J. S., \& Ross, I. (2001). The EVA challenge: Implementing value-added change in an organization. NewYork, USA: John Willey \& Sons, Inc.

Stern, J. M., Stewart, G. B., \& Chew, D. H. (1995). The EVA Financial Management System. Journal of Applied Corporate Finance, 8(2), 32-46. http://dx.doi.org/10.1111/j.1745-6622.1995.tb00285.x

Stewart, G. B. (1991). The Quest for Value. NewYork: Harper Collins Publishers.

Stewart, G. B. (1994). EVA: Fact and Fantasy. Journal of Applied Corporate Finance, 7(2), 71-84. http://dx.doi.org/10.1111/j.1745-6622.1994.tb00406.x

Sundaram, A. K., \& Inkpen, A. C. (2004). The corporate objective revisited. Organization Science, 15(3), 350-363. http://dx.doi.org/10.1287/orsc. 1040.0068

Suresh, S., \& Sengottaiyan, A. (2015). A Study on Shareholders Value Creation and Financial Performance of Selected Auto Mobile Companies in India. International Journal of Humanities Social Sciences and Education(IJHSSE), 2(8), 95-102.

Uyemura, D. G., Kantor, C. C., \& Pettit, J. M. (1996). EVA for banks: value creation, risk management, and profitability measurement. Journal of Applied Corporate Finance, 9(2), 94-109. http://dx.doi.org/10.1111/j.1745-6622.1996.tb00118.x

Vijayakumar, A. (2011). Economic Value Added (EVA) and Shareholders Wealth Creation: A Factor Analytic Approach. Research Journal of Finance and Accounting, 2(12), 22-37.

West, T., \& Worthington, A. C. (2001). The usefulness of economic value-added (EVA) and its components in the Australian context. Accounting, Accountability and Performance, 7(1), 73-90.

Wibowo, P. P., \& Berasategui, R. G. (2008). The relationship between economic value added (EVA®) and market value added (MVA) with reported earnings: An empirical research of 40 listed companies in Indonesia stock exchange for the years 2004-2007. Journal of Applied Finance and Accounting, 1(1), 60-72.

Yaghoob-nejad, A., \& Akaf, A. (2007). The Relationship between Evaluation Performance Measures (EVA, RI, ROS, ROI) and Market Value Added (MVA) in Companies Accepted in Tehran Stock Exchange (TSE). Iranian Economic and Management Journal, 75, 77-89.

Young, D., \& O’Byrne, S. F. (2001). EVA and Value Based Management. NewYork: McGrow-Hill.

\section{Copyrights}

Copyright for this article is retained by the author(s), with first publication rights granted to the journal.

This is an open-access article distributed under the terms and conditions of the Creative Commons Attribution license (http://creativecommons.org/licenses/by/4.0/). 